\title{
In Vitro Assessment of the Cytotoxicity of Cuticle Remover Cosmetics
}

\author{
Ju-Weon Kim ${ }^{1}$, Eun-Joo An ${ }^{2}$, Min-Kyeong Kim ${ }^{1}$, Jeong-Hee Kim ${ }^{1 *}$ \\ ${ }^{1}$ Division of Beauty Design, College of Natural Science, Wonkwang University, Iksan-si, Jeollabuk-do, Korea \\ ${ }^{2}$ Department of Dermatology, College of Medicine, The Catholic University, Seoul, Korea
}

\author{
*Corresponding author: Jeong-Hee Kim, \\ Department of Beauty Design, College of \\ Natural Science Wonkwang University, 460 \\ Iksan-daero, Iksan-si, Jeollabuk-do 54538, \\ Korea \\ Tel.: +82635806898 \\ Fax: +82638507301 \\ Email: jh@wku.ac.kr
}

Ju-Weon Kim and Eun-Joo An contributed equally to this work.

Received January 21, 2021

Revised February 17, 2021

Accepted February 19, 2021

Published March 30, 2021

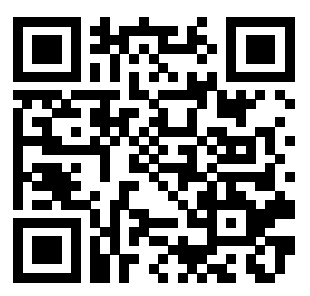

\begin{abstract}
Purpose: Information regarding the hazards of cuticle removers is scarce, and product safety reports are also insufficient. This study aimed to assess the safety of cuticle remover cosmetics. Methods: This study evaluated the safety of the top three commercially sold cuticle removers, Blue cross, Zero cleanser, and Flower vita, which are all widely used in nail care. Human nail matrix cells were isolated and cultured in a defined medium. The toxic effect of cuticle removers on the cultured human nail matrix cells, HS68, and HaCaT, were identified via MTT-assay. The cuticle remover cosmetics were diluted to the following concentrations: 0.5, 1.0, 1.75, 2.5, 10, 20, and $25 \mu \mathrm{g} / \mathrm{mL}$. Results: All three cuticle removers showed significant cytotoxicity to the human nail matrix, HS68, and HaCaT cells in a dose-dependent manner. The viability of cells treated with $10 \mu \mathrm{g} / \mathrm{mL}$ of Blue Cross and Zero cleanser was below 10\%. Conversely, Flower Vita treatment at concentrations of 0.5-20 $\mu \mathrm{g} /$ $\mathrm{mL}$ did not affect the viability (above 70\%) of the nail matrix cells, HS68, and HaCaT. Conclusions: Among the cuticle removers tested, Flower Vita showed the lowest cytotoxic effect in the nail matrix, HS68, and HaCaT cells, proving its safety. This study supports that nail matrix cells are developing as an evaluation method for nail damage.
\end{abstract}

Keywords: Nail cosmetic, Cuticle remover, Nail matrix cell, Potassium hydroxide, MTT assay

\section{Introduction}

네일 서비스의 가장 기본은 네일 케어로, 이때 사용되는 네일 화 장품은 큐티클 리무버이다. 큐티클 리무버는 큐티클을 연화시키 기 위한 네일용 화장품으로 주요성분은 포타슘 하이드록사이드 (potassium hydroxide)와 소듐 하이드록사이드(sodium hydroxide) 이다. 이 성분들은 큐티클 리무버에서 각질 연화의 목적으로 사용되 며, 화장품의 $\mathrm{pH}$ 를 강알칼리성으로 만든다. 네일케어 과정에서 큐 티클 리무버는 큐티클 부위에 직접 도포하며 메탈푸셔를 이용하여 큐티클을 강하게 들어 올리고 니퍼로 큐티클 부위를 제거하면서 손 톱 손상 및 큐티클 주변 피부의 손상이 필연적으로 일어난다(Baran, 2002; Hare \& Rich, 2016).

이러한 부작용을 최소화하기 위해 보습과 영양 공급 효능이 있는
화장품 원료들이 추가된 저자극성의 큐티클 리무버 제품이 출시되 고 있지만(Jefferson \& Rich, 2012; Shim et al., 2019), 포타슘 하 이드록사이드와 소듐 하이드록사이드의 함량 변화와 저자극성의 효 능에 대한 정보는 찾아보기 어려운 실정이다. 또한 Environmental Working Group (EWG)'s Skin Deep에서조차 네일 샵에서 보편적으 로 사용되는 네일 큐티클 리무버의 안전성에 대한 정보가 제한적이 다. 즉, 저자극성 혹은 천연 큐티클 리무버 화장품이라고 광고하는 네일 화장품이 실제적으로 어느 정도 피부 손상을 방지하는지에 대 한 유해성은 파악하기 어렵다.

네일 화장품의 유해성에 관련한 선행연구로는 주로 에나멜, 아 세톤 등에 집중되어 있며(Baran \& André, 2005; Felzenszwalb et al., 2019; Iorizzo, 2007; McLain, 2008; Yun \& Lee, 2017), 큐티 클 리무버의 유해성에 관한 연구는 거의 존재하지 않는다. 따라서 이 
연구에서는 시판되고 있는 네일 전문 화장품 중 샵에서 가장 일반적 으로 사용되고 있는 3 개의 큐티클 리무버를 선정하여 세포독성에 대 한 화장품 안전성을 평가하였다. 안전성 평가는 큐티클 리무버가 적 용되는 실제적 환경을 고려하여 인체에서 채취한 조갑기질세포(nail matrix cell)와 인체각질형성세포(human skin keratinocyte cell, $\mathrm{HaCaT})$, 인체피부섬유아세포(human skin fibroblast cell, HS68)를 사용하여 큐티클 리무버의 세포독성 정도를 평가하였다.

\section{Methods}

\section{Material}

1) Cuticle remover

시판되는 네일 큐티클 리무버의 안전성 평가를 위해 네일 샵에서 일반적으로 사용되는 대표적인 제품 3 개를 선정하였다. 선정제품은 수입화장품인 Universal (VA, USA) 사의 Blue cross 제품과 국내화 장품인 Cuore (Incheon, Korea) 사의 Zero cleanser, Bandi (Seoul, Korea) 사의 Flower vita cuticle care이다.

\section{2) Reagent}

세포의 배양을 위해 HBSS, Antibiotic은 BRL (ON, Canada) 사 의 제품을 사용하였으며, fetal bovine serum (FBS), Dulbecco's Modified Eagle's Medium (DMEM), Keratinocyte growth medium (KGM), Iscove's Modified Dulbecco's Medium (IMDM)은 Gibco BRL (Rockville, USA)사의 제품을 사용하였다. 세포 생존율 측정 을 위해 CellTiter $96^{\circledR}$ Non-Radioactive Cell Proliferation Assay (MTT, Dye Solution \& Stop Solution)는 Promega (Madison, USA) 사의 제품을 사용하였다.

\section{Primary nail matrix cell culture}

조갑기질세포의 배양을 위해 사람의 조갑기질 일부를 조갑 수술 을 통해 채취하였다(연구승인번호: WKUH-2020-10-004). 채취 한 조갑기질을 HBSS에 2x Antibiotic-Antimycotic을 첨가하여 3회 세척하였다. 조직을 배양접시로 옮겨 collagenase type IV (DMEM $3 \mathrm{mg} / \mathrm{mL}$ )를 조직이 잠길 정도로 놓은 후 $\mathrm{CO}_{2}$ 배양기에 2-3 h 동안 방치하고 조직이 완전히 묽은 상태로 변할 때까지 기다린다. 이후 조 직을 $700 \mathrm{rpm}$ 으로 $5 \mathrm{~min}$ 동안 원심분리하여 상측액 제거 후 펠렛을 $\mathrm{DMEM}$ 에 녹여 $37^{\circ} \mathrm{C}, 5 \% \mathrm{CO}_{2}$ 배양 조건에서 배양하였다.

\section{Assessment of cell viability}

\section{1) Cell culture}

일차 배양된 조갑기질세포는 $\mathrm{DMEM}$ 배지에 $10 \% \mathrm{FBS}, 1 \mathrm{x}$ antibiotics를 첨가하여 $37^{\circ} \mathrm{C}, 5 \% \mathrm{CO}_{2}$ 의 조건에서 배양하였다(YOO et al., 1997). HaCaT 세포주는 Addex Bio (Addex Bio, USA)에

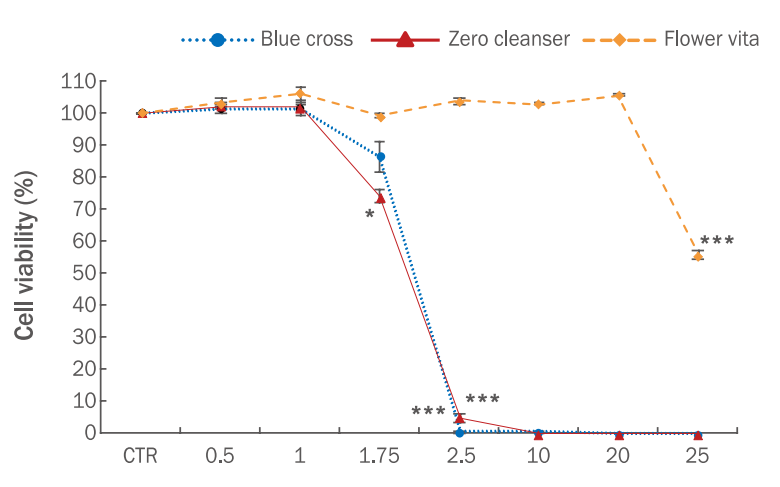

Figure 1. Viability of nail matrix cells exposed to various concentrations of cuticle remover cosmetics.

Data were measured in triplicate. Data are presented by mean $\pm S D$. Data were analyzed using paired $t$-test. *indicates $p<0.05$, **indicates $p<0.001$.

서 분양받아 사용하였다. 분양받은 세포는 $\mathrm{KGM}$ 배지에 $10 \% \mathrm{FBS}$, $1 \mathrm{x}$ antibiotics를 첨가하여 $37^{\circ} \mathrm{C}, 5 \% \mathrm{CO}_{2}$ 의 조건에서 배양하였다. HS68 세포주는 ATCC (USA)에서 분양받아 사용하였다. 분양받은 세포는 IMDM 배지에 $10 \% \mathrm{FBS}, 1 \mathrm{x}$ antibiotics를 첨가하여 $37^{\circ} \mathrm{C}$, $5 \% \mathrm{CO}_{2}$ 의 조건에서 배양하였다.

\section{2) MTT assay}

네일 큐티클 리무버 화장품의 세포독성을 평가하기 위해 조갑기 질세포(nail matrix cell), 인체각질형성세포(keratinocyte cell line, $\mathrm{HaCaT}$ ), 인체피부섬유아세포 (human fibroblast skin cell, HS68) 를 사용하여 MTT assay (3-(4, 5-dimethylthiazol-2-yl)-2, 50diphenyltetrazolium bromide)를 수행하였다. 배양된 조갑기질세 포와 HaCaT, HS68을 96 well에 각 well 당 $1 \times 10^{4}$ cells $/ \mathrm{mL}$ 로 분주 후 $37^{\circ} \mathrm{C}, 5 \% \mathrm{CO}_{2}$ 조건에서 $24 \mathrm{~h}$ 배양하였다(Yoo et al., 1998). 배 양 후 배양액을 제거하고 농도별로 희석한 시료를 각 well 당 $100 \mu \mathrm{L}$ 씩 $24 \mathrm{~h}$ 동안 반응시켰다. 이 후 상층액을 제거하고 $\mathrm{PBS}$ 로 세척하여 시료의 색상이 흡광도에 영향을 미치지 못하도록 하였다. 각 well에 배양액 $100 \mu \mathrm{L}$ 과 dye solution $15 \mu \mathrm{L}$ 을 첨가하여 Incubator에 $4 \mathrm{~h}$ 동안 반응시켰다. 그 후 stop solution $100 \mu \mathrm{L}$ 씩 첨가하여 $1 \mathrm{~h}$ 동안 반응시킨 후 ELISA reader (Spectramax M3; Molecular Devices, $\mathrm{USA})$ 에서 $570 \mathrm{~nm}$ 의 파장으로 흡광도를 측정하였다.

\section{Statistical analysis}

자료분석은 SPSS for Windows version 24.0 program (IBM, $\mathrm{USA})$ 을 이용하여 유의수준 $5 \%$ 에서 검증하였다. 데이터의 기술통 계는 평균과 표준편차, 변화의 값을 구하였다. 결과의 비교분석을 위해 paired t-test와 one-way ANOVA를 실시하였다. One-way ANOVA 결과에 대한 각 집단간의 차이 검증은 Duncan의 사후검증 


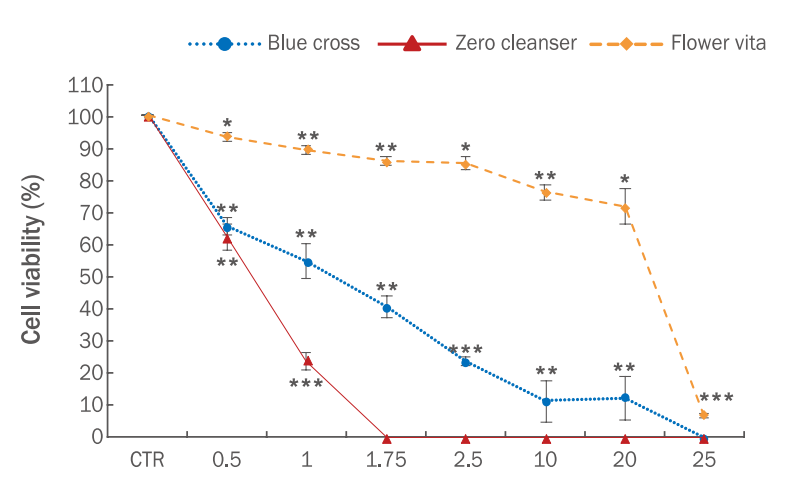

Figure 2. Viability of HaCaT cell exposed to various concentrations of cuticle remover cosmetics.

Data were measured in triplicate. Data are presented by mean \pm SD. Data were analyzed using paired $t$-test. ${ }^{*}$ indicates $p<0.05$, **indicates $p<0.01,{ }^{* * *}$ indicates $p<0.001$.

을 사용하였다.

\section{Results}

큐티클 리무버 화장품의 세포독성을 평가하기 위해 조갑기질세 포를 사용하여 세포 생존율을 측정한 결과는 Figure 1과 같다. 큐티 클 리무버 화장품 시료의 농도가 높아질수록 세포 생존율은 감소하 였다. Blue cross의 경우, $1 \mu \mathrm{g} / \mathrm{mL}$ 농도를 처리하였을때 조갑기질 세포의 생존율이 $101.33( \pm 1.53) \%$ 였고, $1.75 \mu \mathrm{g} / \mathrm{mL}$ 에서는 86.33 $( \pm 5.78) \%$ 로 세포 생존율이 약간 낮아졌지만 $80 \%$ 이상으로 나타났 다. 그러나 $2.5 \mu \mathrm{g} / \mathrm{mL}$ 의 농도에서 세포 생존율이 $0.67( \pm 0.58) \%$ 로 세포가 모두 사멸하였다( $p<0.001)$. Zero cleanser의 경우, $1 \mu \mathrm{g} / \mathrm{mL}$ 농도에서 세포 생존율은 $101.33( \pm 1.00) \%$ 였고, $1.75 \mu \mathrm{g} / \mathrm{mL}$ 농도 에서 $74.00( \pm 2.65) \%$ 로 낮아져 control과 유의한 차이가 나타났다 $(p<0.05)$. 또한 $2.5 \mu \mathrm{g} / \mathrm{mL}$ 농도에서 $5.00( \pm 1.73) \%$ 로 세포 생존율 이 급격하게 낮아졌으며 $10 \mu \mathrm{g} / \mathrm{mL}$ 농도에서는 세포가 모두 사멸하 였다. Flower vita는 $0.5 \mu \mathrm{g} / \mathrm{mL}, 1 \mu \mathrm{g} / \mathrm{mL}, 1.75 \mu \mathrm{g} / \mathrm{mL}, 2.5 \mu \mathrm{g} /$ $\mathrm{mL}, 10 \mu \mathrm{g} / \mathrm{mL}, 20 \mu \mathrm{g} / \mathrm{mL}$ 의 농도에서 약 $100 \%$ 에 가까운 세포 생 존율을 유지하였으나 $25 \mu \mathrm{g} / \mathrm{mL}$ 의 농도에서 55.67 ( \pm 1.53$) \%$ 으로 낮아져 세포독성을 확인하였다 $(p<0.001)$.

인체각질형성세포를 이용하여 큐티클 리무버의 세포독성을 측정 한 결과는 Figure 2 와 같다. Blue cross의 경우, $0.5 \mu \mathrm{g} / \mathrm{mL}$ 농도에 서 $65.67( \pm 3.51) \%$ 의 세포 생존율을 보여 70\%이하의 세포 생존율 로 세포독성을 확인하였다( $p\langle 0.01) .1 .0 \mu \mathrm{g} / \mathrm{mL}, 1.75 \mu \mathrm{g} / \mathrm{mL}, 2.5$ $\mu \mathrm{g} / \mathrm{mL}, 10 \mu \mathrm{g} / \mathrm{mL}, 20 \mu \mathrm{g} / \mathrm{mL}$ 로 농도가 증가함에 따라 세포 생존 율이 감소하였으며 $20 \mu \mathrm{g} / \mathrm{mL}$ 의 농도에서 모든 세포가 사멸하였다. Zero cleanser 제품에서도 $0.5 \mu \mathrm{g} / \mathrm{mL}$ 농도에서 $62.33( \pm 4.73) \%$ 의

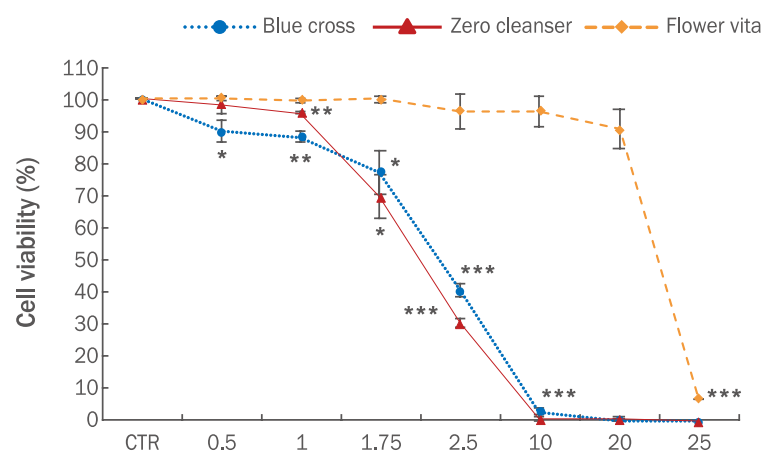

Figure 3. Viability of HS68 cell exposed to various concentrations of cuticle remover cosmetics.

Data were measured in triplicate. Data are presented by mean \pm SD. Data were analyzed using paired $t$-test. "indicates $p<0.05$, ${ }^{* *}$ indicates $p<0.01,{ }^{* * *}$ indicates $p<0.001$.

세포 생존율을 보여 세포독성을 확인하였다 $(p\langle 0.01) .1 .0 \mu \mathrm{g} / \mathrm{mL}$ 농 도에서는 $24.00( \pm 3.46) \%$ 로 나타났고 $1.75 \mu \mathrm{gg} / \mathrm{mL}$ 농도 이후 모든 세포가 사멸하였다. Flower vita 제품은 $0.5 \mu \mathrm{g} / \mathrm{mL}$ 농도에서 세포 생존율이 $93.67( \pm 1.53) \%$ 로 나타났고, $1.0 \mu \mathrm{g} / \mathrm{mL}$ 농도에서 89.67 $( \pm 1.53) \%, 1.75 \mu \mathrm{g} / \mathrm{mL}$ 에서 $86.00( \pm 1.73) \%, 2.5 \% \mu \mathrm{g} / \mathrm{mL}$ 에서 $85.33( \pm 2.52) \%, 20 \mu \mathrm{g} / \mathrm{mL}$ 에서 $71.66(6.35) \%$ 로 나타나 $20 \mu \mathrm{g} /$ $\mathrm{mL}$ 까지의 농도에서 $70 \%$ 이상의 세포 생존율을 확인하였다. 그러나 $25 \mu \mathrm{g} / \mathrm{mL}$ 에서 세포 생존율이 $7.00( \pm 1.00) \%$ 로 감소하여 세포독성 을 확인하였다.

인체피부섬유아세포를 이용하여 큐티클 리무버의 세포독성을 측 정한 결과는 Figure 3 과 같다. Blue cross의 경우, $0.5 \mu \mathrm{g} / \mathrm{mL}$ 농도 에서 HS68의 세포 생존율은 $90.00( \pm 4.00) \%$ 였고, $1.0 \mu \mathrm{g} / \mathrm{mL}$ 농 도에서 $88.33( \pm 2.08) \%$ 였다. $1.75 \mu \mathrm{g} / \mathrm{mL}$ 를 처치하였을 때 77.33 $( \pm 8.08) \%$ 로 농도가 증가할수록 세포 생존율이 낮아졌으며, $2.5 \mu \mathrm{g} /$ $\mathrm{mL}$ 농도에서 $40.67( \pm 2.08) \%$ 로 세포독성을 확인하였다. 또한 10 $\mu \mathrm{g} / \mathrm{mL}$ 이상의 농도에서는 세포가 거의 사멸하였다. Zero cleanser 의 제품을 HS68에 $1.0 \mu \mathrm{g} / \mathrm{mL}$ 로 처치하였을 때 $95.67( \pm 0.58) \%$ 의 높은 세포 생존율을 보였으나 농도가 $1.75 \mu \mathrm{g} / \mathrm{mL}$ 에서는 69.67 ( \pm $8.33) \%$ 로 세포 생존율이 $70 \%$ 이하로 나타났다( $p<0.05)$. 또한 2.5 $\mu \mathrm{g} / \mathrm{mL}$ 의 농도에서는 $30.33( \pm 1.53) \%$ 로 감소하였고 $10 \mu \mathrm{g} / \mathrm{mL}$ 이 하의 농도에서 세포가 모두 사멸하였다. Flower vita의 경우, 0.5 $\mu \mathrm{g} / \mathrm{mL}, 1 \mu \mathrm{g} / \mathrm{mL}, 1.75 \mu \mathrm{g} / \mathrm{mL}$ 의 농도에서 $100 \%$ 에 가까운 세포 생 존율을 유지하였고 $2.5 \mu \mathrm{g} / \mathrm{mL}, 10 \mu \mathrm{g} / \mathrm{mL}, 20 \mu \mathrm{g} / \mathrm{mL}$ 의 농도에서 도 $90 \%$ 이상의 높은 세포 생존율이 나타났다. $25 \mu \mathrm{g} / \mathrm{mL}$ 의 농도에 서부터 $7 \%$ 로 낮아져 세포독성을 확인하였다.

큐티클 리무버 제품을 조갑기질세포, 인체피부섬유아세포, 인체 각질형성 세포를 이용하여 세포독성을 평가하였을 때 세포에 따라 동일 제품에서도 각각 세포 생존율의 차이가 나타났다(Figure 4). 

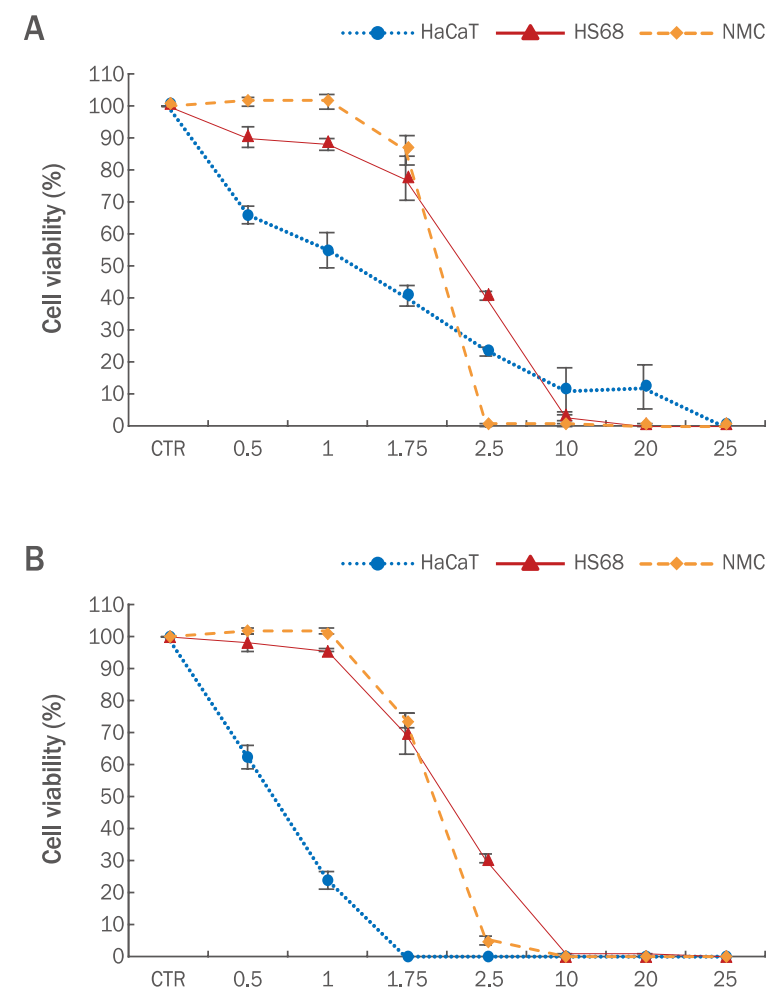

Blue cross 제품을 조갑기질세포, 인체피부섬유아세포, 인체각질 형성 세포를 이용하여 세포독성을 평가하였을 때 $0.5 \mu \mathrm{g} / \mathrm{mL}, 1 \mu \mathrm{g} /$ $\mathrm{mL}, 1.75 \mu \mathrm{g} / \mathrm{mL}$ 에서는 조갑기질세포의 세포 생존율이 가장 높게 나타났으며 다음으로 인체피부섬유아세포, 인체각질형성세포 순으 로 나타났다. Blue cross 제품 농도가 $2.5 \mu \mathrm{g} / \mathrm{mL}$ 에서는 조갑기질 세포가 모두 사멸하였으나, 반면 인체피부섬유아세포의 생존율은 40.67 ( \pm 2.08$) \%$ 로 가장 높게 나타났다. $10 \mu \mathrm{g} / \mathrm{mL}$ 이상의 농도에 서는 조갑기질세포와 인체피부섬유아세포의 경우 세포가 모두 사멸 하였으며, 인체각질형성세포 또한 약 $10 \%$ 정도의 세포 생존율을 보 여 세포가 거의 사멸하였음을 알 수 있었다(Figure 4A).

Zero clenser 제품을 조갑기질세포, 인체피부섬유아세포, 인체각 질형성세포를 이용하여 세포독성을 평가한 결과를 살펴보면(Figure 4B), $0.5 \mu \mathrm{g} / \mathrm{mL}, 1 \mu \mathrm{g} / \mathrm{mL}, 1.75 \mu \mathrm{g} / \mathrm{mL}$ 농도에서 조갑기질세포 와 인체피부섬유아세포는 $70 \%$ 에 가까운 세포 생존율을 보인 반면 인체각질형성세포에서는 가장 저농도의 $0.5 \mu \mathrm{g} / \mathrm{mL}$ 에서 62.33 ( \pm 4.73)\%의 세포 생존율을 보였다. $2.5 \mu \mathrm{g} / \mathrm{mL}$ 농도에서는 모든 세포 의 세포 생존율이 급격히 감소였다. Zero clenser 제품의 경우 인체 각질형성세포에서의 세포 생존율이 다른 제품에 비해 현저히 낮게 나타나 다른제품에 비해 인체각질형성세포에 대한 세포독성이 있음 을 확인하였다.

조갑기질세포, 인체피부섬유아세포, 인체각질형성세포를 이용하 여 Flower vita 제품의 세포 생존율을 평가한 결과는 Figure $4 \mathrm{C}$ 와 같다. Flower vita 제품은 $0.5 \mu \mathrm{g} / \mathrm{mL}$ 에서 $20 \mu \mathrm{g} / \mathrm{mL}$ 농도까지 조갑

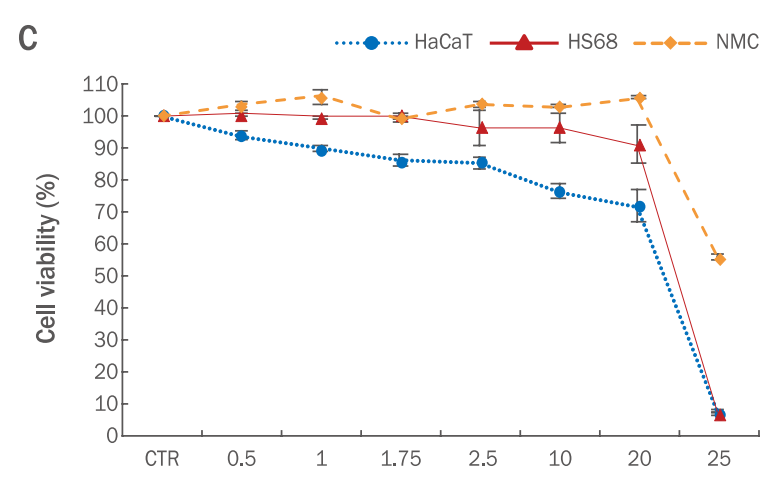

Figure 4. Cytotoxicity assay of cultured human nail matrix, dermal fibroblast, and human keratinocyte cells exposed to cuticle remover cosmetics.

(A), Viability of cultured human nail matrix, dermal fibroblast, and human keratinocyte cells exposed to Blue cross; (B), Viability of cultured human nail matrix, dermal fibroblast, and human keratinocyte cells exposed to Zero cleanser. (C), Viability of cultured human nail matrix, dermal fibroblast, and human keratinocyte cells exposed to Flower vita. Data were measured in triplicate. Data are presented by mean \pm SD. NMC, nail matrix cell.

기질세포, 인체피부섬유아세포, 인체각질형성세포 모두 약 $70 \%$ 이 상의 세포 생존율을 보여 세포독성에 대한 안전성을 확인할 수 있었 다. $25 \mu \mathrm{g} / \mathrm{mL}$ 농도에서는 인체피부섬유아세포와 인체각질형성세 포에서 세포가 거의 사멸하였으며, 조갑기질세포에서는 55.67 ( \pm 1.53)\%의 세포 생존율을 보였다.

\section{Discussion}

큐티클 리무버를 손톱 주변에 사용하면 조갑을 둘러싸고 있는 표 피에 일차적으로 직접 접촉하고 표피를 통해 흡수된 큐티클 리무버 는 진피에도 영향을 미친다. 또한 조갑을 형성하는 조갑기질에도 흡 수되어 생물학적 효과가 나타날 가능성이 있다. 따라서 이 연구에 서 시판 큐티클 리무버의 안전성 평가를 위해 배양조갑기질세포, $\mathrm{HaCaT}, \mathrm{HS} 68$ 등의 세 종류의 세포를 사용하였다.

네일 화장품의 부작용에 관한 선행연구는 여러 가지 종류의 네일 화장품이 피부에 미치는 영향을 in vivo와 in vitro를 통해 분석한 연 구가 보고되고 있다(Mendelsohn et al., 2016; Taofiq et al., 2019). 특히 세포독성 분석법이 화장품 개발 단계에서 독성 물질 여부를 확 인하는 실험 법이 보고되고 있으며(Hamid et al., 2004; Kim et al., 2019a; Ryu et al., 2019), 세포독성평가는 인체의 유해성을 확인할 수 있는 적용이다(Tomankova et al., 2011; Kim et al., 2019b).

따라서 이 연구에서는 시판 큐티클 리무버 화장품이 피부 및 손 
톱 기질에 미치는 영향을 분석하기 위해 세포독성 분석법 중 MTT assay를 시행한 결과 배양조갑기질세포, HaCaT, HS68 세포 주 모 두에서 농도 의존적으로 세포 생존율이 감소하는 결과를 보였다.

조갑기질세포를 이용한 세포독성에 관한 연구 결과는 매우 드물 다. 인체에서 조갑기질 일부를 수술적으로 채취한다는 것이 매우 어 렵기 때문이다. 조갑기질에 손상이 일어나면 조갑에 변형이 생기는 심각한 후유증이 나타날 가능성이 높다. 항진균제가 조갑기질세포 의 생존에 미치는 영향을 보고한 보고가 있지만 네일 화장품 관련 연 구에 적용하여 실험한 보고는 거의 없다(Yoo et al, 1998). 이 연구 에서는 건강한 사람에서 채취한 조갑기질 일부를 가지고 일차배양 을 시도하여 배양세포주를 확립하였다. 큐티클 리무버의 세포독성은 배양조갑기질세포와 HS68 세포주에서 유사한 결과가 나타났지만 $\mathrm{HaCaT}$ 세포주에서는 배양조갑기질세포와 HS68 세포에 비해 독성 효과가 상대적으로 강한 것으로 측정되었다. 이러한 세포독성 효과 의 차이는 큐티클 리무버가 본질적으로 가지고 있는 약리학적 특성 과 함께 조갑기질세포의 생물학적 특성에서도 기인한다고 볼 수 있 다.

\section{Conclusion}

이 연구에서는 시판 큐티클 리무버 화장품 중 가장 일반적으로 사 용되는 Blue cross, Zero cleanser, Flower vita cuticle care의 세 제 품을 선정하여 조갑기질세포, 인체각질형성세포, 인체피부섬유아세 포를 이용하여 제품에 대한 세포 독성을 평가하였다.

세포독성 측정 결과, 세 가지 제품 중 Flower vita 제품이 조갑기 질세포, 인체각질형성세포, 인체피부섬유아세포 모두 $20 \mu \mathrm{g} / \mathrm{mL}$ 농 도에서 $70 \%$ 이상으로 가장 높은 세포 생존율을 보였다. 이 결과를 통해 Flower vita 제품이 조갑과 이를 둘러싸고 있는 인체 조직에 가 장 손상을 적게 주는 것을 알 수 있었다. 그러나 인체각질형성세포에 서는 세 가지 큐티클 리무버 모두에서 세포 독성이 강한 것으로 측정 되었다. 이러한 차이는 큐티클 리무버의 구성 성분이 세포에 미치는 생물학적 특성에서 기인하는 것으로 사료된다.

결론적으로 Flower vita 제품이 세포 독성 측면에서 가장 안전한 제품임을 알 수 있었다. 큐티클 리무버 화장품의 경우 조갑과 주위 피부에 흡수되는 제품의 안전성을 측정하기 위해서 조갑기질세포에 대한 독성도 함께 측정해야 신뢰할 만한 결과로 인정받을 수 있을 것 이다. 따라서 조갑기질세포 일차배양법과 세포독성 측정법은 조갑의 손상을 객관적으로 평가할 수 있는 유용한 방법으로 활용이 가능할 것이다.

이 연구는 배양이 어려운 인체 조갑기질세포의 일차배양법을 확립 하여 제시하였으며, 시판 큐티클 리무버 화장품에 대한 세포독성 평 가 결과를 객관적으로 제시하였습니다. 이를 기반으로 저자극의 안 전성이 확보된 큐티클 리무버 화장품의 개발이 후속되어야 할 것으
로 사료됩니다.

This work is part of Ju-Weon Kim's Masters' degree thesis at WonKwang University, Iksan-si, Korea

\section{Acknowledgements}

Following are results of a study on the "Leaders in Industry-university Cooperation +" Project, supported by the Ministry of Education and National Research Foundation of Korea.

\section{Author's contribution}

JWK and EJA contributed equally to this work. JWK and EJA designed all experimental investigations. MKK performed experiments and wrote manuscript. JHK oversaw the project.

\section{Author details}

Ju-Weon Kim (Graduate student), Department of Beauty Design, Wonkwang University, 460 Iksan-daero, Iksansi, Jeollabuk-do 54538, Koera; Eun-Joo An (Researcher). Department of Dermatology, College of Medicine, The Catholic University, 222, Banpo-daero, Seocho-gu, Seoul 06591, Korea; Min-Kyeong Kim (Graduate student), Department of Beauty Design, Wonkwang University, 460 Iksan-daero, Iksan-si, Jeollabuk-do 54538, Koera; Jeong-Hee Kim (Professor), Department of Beauty Design, Wonkwang University 460, Iksan-daero, Iksan-si, Jeollabuk-do 54538, Korea.

\section{References}

Baran R. Nail beauty therapy: an attractive enhancement or a potential hazard. Journal of Cosmetic Dermatology, 1: 24-29, 2002.

Baran R, André J. Side effect of nail cosmetics. Journal of Cosmetic Dermatology, 4: 204-209, 2005.

Felzenszwalb I, da Silva Fernandes A, Brito LB, Oliveira GAR, Silvia PAS, Arcanjo ME, da Costa Marques MR, Vicari T, Leme DM, Cestari MM, et al. Toxicological evaluation of nail polish waste discarded in the environment. Environmental Science and Pollution Research, 26: 27590-27603, 2019. 
Hamid R, Rotshteyn Y, Rabadi L, Parikh R, Bullock P. Comparison of alamar blue and MTT assays for high through-put screening. Toxicology In Vitro, 18: 703-710, 2004.

Hare A, Rich P. Nail physiology and grooming. Cosmetic Dermatology, 2: 207-216, 2016.

Iorizzo M, Piraccini BM, Tosti A. Nail cosmetics in nail disorders. Journal of Cosmetic Dermatology, 6: 53-58, 2007.

Jefferson J, Rich P. Update on nail cosmetics. Dermatologic Therapy, 25: 481-490, 2012.

Kim MJ, Park K, Kim JH. Safety assessment of natural foundation for atopy. Asian Journal of Beauty and Cosmetology, 17: 169-177, 2019a.

Kim J, Park JG, Lee CM, Kim SG. Effect of the pine cone extract phytochemical and physiological activity on HaCaT cells. Asian Journal of Beauty and Cosmetology, 17: 353-363, 2019b.

McLain VC. Final report of the addendum to the to the safety assessment of n-butyl alcohol as used in cosmetics. International Journal of Toxicology, 27: 53-69, 2008.

Mendelsohn E, Hagopian A, Hohhman K, Mutt CM, Lorenzo
A, Congleton J, Webster TF, Stapleton HM. Nail polish as a source of exposure to triphenyl phosphate. Environmental International, 86: 45-51, 2016.

Ryu JY, Rhie SJ, Lim KH, Choi YE, Han HS, Yang HO, Na EJ. Inhibitory effects of prunin on photo-aging in human keratinocytes (HaCaT) damaged by UVB radiation. Asian Journal of Beauty \& Cosmetology, 17: 139-147, 2019.

Taofiq O, Rodrigues F, Barros L, Barreiro MF, Ferreira ICFR, Oliveira MBPP. Mushroom ethanolic extracts as cosmeceuticals ingredients: safety and ex vivo skin permeation studies. Food and Chemical Toxicology, 127: 228-236, 2019.

Yoo JH, Chung JH, Eun HC. Effects of several antifungal agents on cultured human nail matrix cells and epidermal keratinocytes. Korean Journal of Dermatology, 36: 415-421, 1998.

Yoo HJ, Eun HC, Lee YH. Culture of nail matrix cells. Annals of Dermatology, 9: 242-245, 1997.

Yun $\mathrm{CH}$, Lee SH. Study on the safety review and management system of hazardous substances in nail products. Journal of the Korea Convergence Society, 8: 439-445, 2017. 


\section{국문초록}

\section{큐티클 리무버 화장품의 세포독성평가}

김주원 ${ }^{1}$ 안은주 ${ }^{2}$, 김민경 ${ }^{1}$, 김정희 ${ }^{1 *}$

${ }^{1}$ 원광대학교 자연과학대학 뷰티디자인학부, 전라북도 익산시, 한국

${ }^{2}$ 가톨릭대학교 피부면역학교실, 서울, 한국

목적: 네일 케어에서 사용되는 큐티클 리무버 화장품에 대한 안전성 평가는 미비한 실정이다. 따라서 시판되고 있는 네일 전문 화 장품 중 샵에서 가장 일반적으로 사용되고 있는 3 개의 큐티클 리무버를 선정하여 세포독성에 대한 화장품 안전성을 평가하고자 하 였다. 방법: 큐티클 리무버 화장품의 유해성평가는 피부관련 배양세포뿐 아니라 조갑기질세포를 이용하여 세포독성을 평가하였다. 따라서 인체 조갑기질 일부를 조갑 수술을 통해 채취하여 조갑기질세포를 배양하였다. 배양된 조갑기질세포, 인체피부섬유아세포, 인체각질형성세포에 큐티클 리무버 화장품을 농도별 $(0.5 \mu \mathrm{g} / \mathrm{mL}, 1.0 \mu \mathrm{g} / \mathrm{mL}, 1.75 \mu \mathrm{g} / \mathrm{mL}, 2.5 \mu \mathrm{g} / \mathrm{mL}, 10 \mu \mathrm{g} / \mathrm{mL}, 20 \mu \mathrm{g} / \mathrm{mL}, 25$ $\mu \mathrm{g} / \mathrm{mL}$ )로 희석하여 MTT assay를 수행하였다. 결과: 조갑기질세포, 인체피부섬유아세포, 인체각질형성세포에 큐티클 리무버 화 장품을 농도별로 처치하였을 때 세포 생존율이 농도의존적으로 나타났다. Blue cross와 Zero cleanser $10 \mu \mathrm{g} / \mathrm{mL}$ 농도에서 조갑기 질세포와 인체피부섬유아세포, 인체각질형성세포가 거의 사멸하였다. Flower vita 제품은 조갑기질세포, 인체각질형성세포, 인체

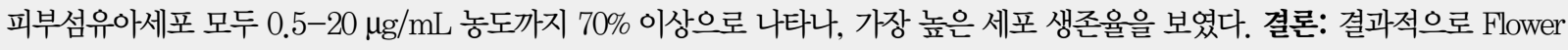
vita 제품이 조갑기질세포, $\mathrm{HS} 68, \mathrm{HaCaT}$ 세포 모두 세포독성이 가장 낮아 선정된 세 개의 제품 중 세포독성에 대한 안전성이 가장 우수함을 확인하였다. 또한 조갑기질세포의 배양을 통한 세포독성 측정법은 조갑의 손상을 객관적으로 평가할 수 있는 유용한 방법 일 것으로 사료된다.

핵심어: 네일 화장품, 큐티클 리무버, 조갑기질세포, 포타슘 하이드록사이드, 세포독성

Following are results of a study on the "Leaders in Industry-university Cooperation +" Project, supported by the Ministry of Education and National Research Foundation of Korea.

\section{참고문헌}

김민정, 박건, 김정희. 아토피용 천연파운데이션의 안전성 평가. 아시안뷰티화장품학술지, 17: 169-177, 2019. 김진, 박정기, 이창문, 김수관. 솔방울 추출물의 파이토케미컬 성분 평가 및 $\mathrm{HaCaT}$ 세포이동 평가. 아시안뷰티화장품학술 지, 17: 353-363, 2019.

심하은, 노대영, 김지민, 김도연, 남명석, 김동욱. 쉘락/젤라틴을 함유한 저자극 친환경 매니큐어의 개발. 한국화공학회지, 57:22-27, 2019

류지영, 이승자, 임계화, 최영은, 한효선, 양현옥, 나은주. Prunin의 자외선 B에 의해 손상된 인간 각질형성세포 (HaCaT) 에 대한 광노화 억제 효과. 아시안뷰티화장품학술지, 16:139-147, 2019.

유재학, 정진호, 은희철. 배양된 인체 조갑 기질세포와 표피 각질형성세포에 미치는 수종 항진균제의 영향. 대한피부과학 회지, $36: 415-421$.

윤초희, 이승희. 네일 제품의 유해물질 안전성 검토 및 관리제도 개선 연구. 한국융합학회논문지, 8: 439-445, 2017. 


\section{中文摘要}

\section{指甲外皮去除剂化妆品的细胞毒性评价}

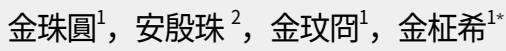

圆光大学自然大学美容设计学科, 全罗北道盆山市, 韩国

${ }^{2}$ 天主教大学佊肤免疫学教室, 首尔, 韩国

目的：近对指甲外皮去除剂危害的信息很少，产品安全报告也不足。因此这项研究旨在评估指甲外皮去除剂的 安全性。方法: 不仅使用与皮肤有关的培养细胞, 而且使用指甲基质细胞对指甲外皮去除化妆品进行毒性评 价。通过指甲手术收集一部分人指甲基质，并培养指甲基质细胞。按浓度 $(0.5 \mu \mathrm{g} / \mathrm{mL}, 1.0 \mu \mathrm{g} / \mathrm{mL}, 1.75 \mu \mathrm{g} /$ $\mathrm{mL}, 2.5 \mu \mathrm{g} / \mathrm{mL}, 10 \mu \mathrm{g} / \mathrm{mL}, 20 \mu \mathrm{g} / \mathrm{mL}, 25 \mu \mathrm{g} / \mathrm{mL}$ ）将指甲外皮去除化妆品应用于培养的指甲基质细胞，人 皮肤成纤维细胞和人角质形成细胞进行MTT分析。结果: 当在指甲基质细胞, 人皮肤成纤维细胞和人角质形成 细胞上对指甲外皮去除剂化妆品进行不同浓度的处理后, 发现细胞活力是浓度依赖性的。在Blue Cross和Zero Cleanser浓度为 $10 \mu \mathrm{g} / \mathrm{mL}$ 时，指甲基质细胞，人皮肤成纤维细胞和人角质形成细胞几乎无生存。Flower Vita产 品显示出最高的细胞存活率，在所有指甲基质细胞，人角质形成细胞和人皮肤成纤维细胞中，浓度为 $0.5-20 \mu \mathrm{g} /$ $\mathrm{mL}$ 时，显示出 $70 \%$ 以上的存活率。结论：在测试的表皮去除剂中，Flower Vita在指甲基质，HS68和HaCaT细 胞中显示出最低的细胞毒性作用, 证明了其安全性。另外, 通过培养指甲基质细胞的细胞毒性测量方法被认为 是客观评估指甲损伤的有用方法。

关键词: 指甲化妆品，指甲外皮去除剂，指甲基质细胞，氢氧化钾，细胞毒性 